
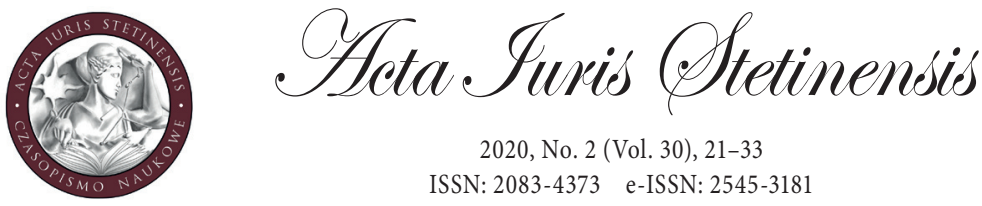

2020, No. 2 (Vol. 30), 21-33

ISSN: 2083-4373 e-ISSN: 2545-3181

DOI: $10.18276 /$ ais.2020.30-02

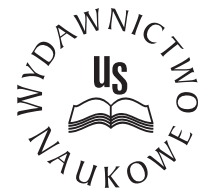

Michał Ignasiak

MA

University of Lodz, Poland

Faculty of Law and Administration

e-mail: ignasiakmich@wp.pl

OPEN ACCESS

ORCID ID: 0000-0003-3187-5179

\title{
Refusal to adjourn a hearing due to the defender's being ill vs. execution of the right of defence - comments on Article 378a $\$ 1$ of the Polish Code of Criminal Procedure
}

\begin{abstract}
The object of this paper constitutes the issue regarding the principle of the right of defence in Polish criminal proceedings in the context of the new regulation included in Article 378a par. 1 of the Code of Criminal Procedure, which came into effect on 5 October 2019 (as a result of the entry into force of the Act of 19 July 2019 amending the Act on the Code of Criminal Procedure and certain other acts, Dz.U. (Journal of Laws) of 2019 item 1694). To be precise, the court's refusal to take into consideration the defender's motion for adjournment of the term of a hearing due to his or her illness confirmed with a sick leave issued by a pathologist.

The aim of this study was to draw attention to the questionable character of the aforementioned Article in terms of the procedural safeguards of the accused. The paper presents the circumstances, as well as the state of proceedings, indicating the evidence of violation of the principle of the right of defence in criminal proceedings by improper application of Article 378a par. 1 of the Code of Criminal Procedure. A formal-dogmatic method has been used.

Furthermore, the author's intention was to present the irrationality of the Polish legislator introducing solutions contrary to the model of criminal procedure, including, in particular, violation of the constitutionally guaranteed rights of the accused.
\end{abstract}

Keywords: principle of the right of defence, procedural safeguards, adjournment of the term of a hearing 


\section{Introduction}

This paper concerns the issue related to the violation of the accused's right of defence in a criminal procedure and, to be more precise, the state of proceedings consisting in the court's refusal to take into consideration the defender's motion for adjournment of the term of a hearing due to his or her illness confirmed with a sick leave issued by a pathologist. This is an issue which, in terms of the accused's procedural safeguards, as well as the practical aspect of the profession of an advocate or attorney-at-law acting as a defender in criminal proceedings, deserves attention. The above issue seems to be valid, since, in practice, it occurred as a result of entry into force of the Act of 19 July 2019 on the amendment to the Act - the Code of Criminal Procedure and certain other acts (Dz.U. (Journal of Laws of 2019 item 1694), since, as of 5 October 2019, the new Article 378a of the Code of Criminal Procedure introduced extremely unfavourable solutions in the scope concerning the actual right of defence in criminal proceedings. The aforementioned provision allows for conducting by the court the hearing of evidence in the absence of the accused or his or her defender, which has been duly justified. Such a solution in a democratic rule of law, taking into account the constitutionally guaranteed right of defence of the accused in criminal proceedings, seems to be inadmissible although - as shown in the practice of law-making in Poland - possible. The above solution of the legislator is equally unjust, as well as inconsiderate with regard to advocates or attorney-at-laws (acting as defenders in criminal cases) who are currently, in a way, expected not to permit the occurrence on their part of the inability to perform their duties due to reasons not attributed to them, such as e.g. serious illness, breakdown of communication means or death of a close relative. Incidentally, the issue concerning the rationality of the Polish legislator in the scope of broadly understood legal solutions which have been adopted in recent years should be put aside, since this issue significantly exceeds the technical possibilities of the form of a scientific paper.

\section{The principle of the right of defence}

To begin with, it should be noted that the right of defence is one of the guiding principles of criminal proceedings. ${ }^{1}$ Among others, respecting this principle in practice decides upon whether given criminal proceedings deserve to be described as a fair trial, i.e. proceedings respecting procedural principles and safeguards vested in the

1 Misztal, P., in: Świecki, D. (ed.), Meritum. Postępowanie karne, Warszawa 2019, p. 136. 
participants of a criminal procedure. P. Wiliński rightly notes that such procedure involves compliance with numerous directives regarded to be the main principles of criminal procedure. ${ }^{2}$ In other words, the theoretical guarantee of certain procedural standards providing for the protection of the interests and rights of specific subjects to criminal proceedings is not sufficient to state that the proceedings are reliable (fair). It is, in fact, necessary to observe them in practice. The significance of the right of defence in criminal proceedings is aptly illustrated by the thesis of the Supreme Court in its judgement of 2 December 2015, III KK 309/15, in compliance with which the accused's right to assistance provided by a professional constitutes one of the fundamental standards of contemporary criminal proceedings, whereas the defender's participation in the hearing - covering participation both before the first instance court and the court of appeal - is of a safeguarding character. ${ }^{3}$ In other words, the principle of the right of defence in criminal proceedings is of fundamental significance and should be respected. F. Prusak notes that execution of the right of defence is of utmost significance in a fair criminal procedure. ${ }^{4}$ It should be noticed that the new solution adopted by the legislator in the scope concerning conducting the hearing of evidence in the absence of a defender (which has been duly justified) poses a real threat to respecting the principle of the right of defence. Another consequence of the above is the fact that in the case of violating the aforementioned principle constituting one of the bases of fair criminal proceedings, the issue whether these proceedings (both in concreto and in abstracto) will be reliable remains doubtful. Moreover, it should be noticed that the principle of the right of defence vested in the accused was, in a way, restricted by the legislator to the benefit of the principle of concentration of the procedural material, which, according to the author, should not take place due to the significance in the criminal proceedings of the possibility of enjoying assistance provided by a defender being a professional. M. Siewierski rightly notes that the principle of concentration in criminal cases is of major social significance; however, thorough examination of all the circumstances of a case and ensuring that the accused is not wrongly convicted, even though it prolongs proceedings, constitutes a fundamental guarantee for the accused that the ruling is just. ${ }^{5}$ It is obvious that in the hierarchy of the principles of the criminal procedure, the principle of the right of defence is more important than the principle of concentration. The former belongs, in fact, to the so-called guiding

2 Cf. Wiliński, P., Pojęcie rzetelnego procesu karnego, in: Wiliński, P. (ed.), Rzetelny proces karny, LEX.

3 See: Judgement of the Supreme Court of 2 December 2015, LEX no. 1943849.

4 Cf. Prusak, F., Kodeks postępowania karnego. Komentarz, LEX.

5 Cf. Siewierski, M., in: Siewierski, M. et al., Postępowanie karne w zarysie, Warszawa 1971, p. 50. 
procedural principles, i.e. principles that indicate the main and most important features of criminal proceedings of the greatest significance in the criminal procedure. ${ }^{6}$ However, one should take into account the fact that, in practice, the proper application of the possibility provided by Article 378a of the Code of Criminal Procedure will depend on the rational approach to this issue of the court before which the proceedings are pending. Provided that conducting the hearing of evidence in the absence of the defender in the state of proceedings in which the case is multithreaded, and there are at least a few accused persons, and the given thread being the object of the hearing of evidence on a given term of the hearing does not concern the accused whose defender did not appear, this new provision is a valid solution. In such a case, conducting the hearing will be justified and appropriate, and the proceedings will not be groundlessly prolonged. Nevertheless, in other cases when there is only one accused, conducting the proceedings in the absence of the defender applying for adjournment of the term of the hearing is inappropriate and should not take place. In such a state of proceedings, actual and constitutional safeguarding of the accused's right of defence in criminal proceedings becomes only a written declaration of the legislator, which is not respected in legal practice.

\section{“Duly justified cases" within the meaning of Article 378a $₫ 1$ of the Code of Criminal Procedure}

In compliance of the wording of the new provision of Article 378a par. 1 of the Code of Criminal Procedure, in the case of the duly justified absence of the accused or his or her defender, the court has the right to conduct the hearing of evidence in particularly justified cases. Nonetheless, the legislator does not specify what should be understood by the phrase "especially justified cases", whereas the meaning of the phrase concerning a duly justified absence is known. This catalogue does, in fact, include a sick leave issued by a pathologist, which directly results from the contents of the provision of Article 117 par. 2a of the Code of Criminal Procedure. It should also be noted that, in accordance with a judgment of the Supreme Court, ${ }^{7}$ it is possible to present a relevant certificate issued by a court physician at a later date. Thus, it is not necessary to present the court with a certificate before or in the course of a hearing that cannot be attended by the accused or their defender. However, the phrase "in especially justified cases" is blurred to the extent that it

6 See: Tylman, J., in: Grzegorczyk, T. and Tylman, J., Polskie postepowanie karne, Warszawa 2014, p. 76.

7 Cf. Judgment of the Supreme Court of 9 August 2017, II KK 237/17, LEX no. 2337348. 
allows for possible abuse by the procedural authority, resulting in the violation of the accused's right of defence. In fact, there are no obstacles to consider the absence of witnesses summoned on the term of the main hearing as an "especially justified case". However, it should be underlined that the fact of conducting the hearing of evidence despite the justified absence of the defender demanding adjournment of a hearing constitutes a violation of the right of defence in the majority of states of proceedings. In compliance with the provision of Article 6 of the Code of Criminal Procedure, the accused has the right to assistance provided by a defender who, in criminal proceedings, may be both an advocate and attorney-at-law. The right of defence is also provided for in the Constitution of the Republic of Poland, in Article 42 par. 2, in compliance with which anyone against whom criminal proceedings have been brought has the right of defence. Furthermore, the provision of Article 6 of the European Convention on Human Rights implies that the accused has the right to assistance provided by a defender, as well as to defend himself or herself in person or through the assistance of a defender who has been appointed. This should be understood as, among others, the right of the accused consisting in active participation in the examination of witnesses, expert witnesses or other co-accused individuals at the main hearing. ${ }^{8}$ The opinion of the Supreme Court, according to which it is inadmissible to limit the accused's personal recourse to right of defence, is relevant and important. ${ }^{9}$ Concerning execution of that right by the accused, A. Murzynowski rightly noted that it is necessary to enable the accused to take an active part in a hearing by submitting motions or expressing their opinion on all the issues reviewed by the court, regardless of the activity of their defender. ${ }^{10}$ However, it should be noticed that whereas the issue regarding the discussed Article seems to be invalid in the state of proceedings where the accused enjoys the assistance of more than one defendant (see the provision of Article 77 of the Code of Criminal Procedure), and one of them cannot participate in court proceedings, as well as in the case of the obligatory defence (provision of Article 79 and 80 of the Code of Criminal Procedure), in practice, the proceedings in which the accused is represented by one professional are prevailing. Therefore, in such a situation, not taking into consideration the motion submitted by the only defender, including the sick leave issued by an authorised pathologist (confirming the unavailability due to being ill - in compliance with Article 117 par. 2a of the Code of Criminal Procedure), for the adjournment of the term of the hearing and,

8 See Kosonoga, J., in: Stefański, R. and Zabłocki, S., (eds.), Kodeks postępowania karnego. Tom I. Komentarz do art. 1-166, LEX.

9 Judgment of the Supreme Court of 18 September 1973, V KRN 355/73, LEX no. 18695.

10 Cf. Murzynowski, A., Istota i zasady procesu karnego, Warszawa 1994, p. 276. 
in consequence, conducting by the court the hearing of evidence, this constitutes a violation of the actual, as well as the constitutionally guaranteed right of defence of the accused in criminal proceedings. Incidentally, it should be underlined that such a violation will not apply to the situation when the defender solely presents the sick leave issued by a pathologist without an explicit motion for the adjournment of the term of the hearing. ${ }^{11}$

\section{Procedural activities of the court}

A further part of the provision of Article 378a par. 1 of the Code of Criminal Procedure indicates that the court can "especially" conduct procedural activities consisting in examining witnesses who appeared at the term of the hearing, i.e. the court de facto has the right to conduct the relevant hearing of evidence. However, the issue of whether, after the conducted proceedings and exhausting evidentiary proceedings, the court may close the court proceedings and give the floor to the parties to the proceedings remains doubtful. It should be assumed that this is inadmissible, since the provision of Article 378a par. 1 of the Code of Criminal Procedure solely stipulates conducting a hearing of evidence, which certainly does not include submitting final statements. Furthermore, it should be indicated that court proceedings consisting in conducting the hearing of evidence in compliance with Article 378a par. 1 of the Code of Criminal Procedure are admissible even in the state of proceedings in which the accused has not yet made a statement. At this point, another doubt arises with regard to whether the necessity (in the court's opinion) consisting in receiving the statement from the accused at the first term of the hearing, at which his or her defender, who has duly justified their absence and submitted the motion for the adjournment of the term of the hearing, is absent, should be considered as an especially justified case pursuant to the provision of Article 378a of the Code of Criminal Procedure. The state of proceedings in which the accused states that he or she submits a motion for conducting the hearing in the absence of his or her defender and, as a result, his or her explanations are received, and for conducting the hearing of evidence, at first glance seems to be an appropriate solution for not violating the right of defence of the accused. However, such a conclusion may be premature and incorrect. One should not omit procedural solutions such as those provided for e.g. in Article 387 of the Code of Criminal Procedure, i.e. the right of the accused to voluntarily submit oneself to penalty. In compliance with the aforementioned provision, the accused is vested with such

11 See: Judgement of the Supreme Court of 11 January 2007, V KK 330/06, LEX no. 459583. 
a right, which is limited in time. This means that the accused can exercise the right until the end of the first examination of all accused persons at the main hearing. If, at the stage preceding the hearing, the issue concerning e.g. the conditions of the accused's voluntary submission to penalty and the penalty, means of punishment, forfeiture or compensation measure have not been specified, then, in the case of a lack of assistance provided by a professional - advocate or attorney-at-law, it seems to be inadmissible. However, incidentally, it should be indicated that the provision of Article 387 par. 1 of the Code of Criminal Procedure stipulates admissibility of a court-appointed defender in the state of proceedings in which the accused is not represented by a defender of his or her own choosing. Thus, it remains to be clarified whether the accused's right of defence is violated in the aforementioned situation, i.e. the justified absence at the hearing of the defender submitting a motion for the adjournment thereof, as well as the lack of the accused's consent to conduct the hearing in the absence of his or her defender (willing to voluntarily submit oneself to penalty pursuant to Article 387 of the Code of Criminal Procedure) by nonadjournment of the term of the hearing and conducting the hearing of evidence by the court. It seems that in a thus described state of proceedings, the accused's right of defence is violated irrespective of whether or not he or she exercises the right of voluntary submission to penalty. It is also indirectly indicated by the regulation included in the provision of Article 387 par. 1 last sentence of the Code of Criminal Procedure, in compliance with which in a situation when the accused does not have a chosen defender, the court has the possibility to appoint such a defender if the accused submits a relevant motion. Irrespective of the above, even in the state of proceedings in which the defender duly justifies his or her absence, submits a motion for the adjournment of the term of the hearing, and the accused present on the specified term (declaring the will of voluntary submission to penalty) gives consent to conduct the proceedings in the absence of the defender, the court should adjourn the hearing irrespectively of such circumstances. In a case when the court fails to do so, the defender will be able to raise in the remedy at law an objection regarding the violation of the accused's right of offence, i.e. Article 6 of the Code of Criminal Procedure in conjunction with Article 387 of the Code of Criminal Procedure in conjunction with Article 378a of the Code of Criminal Procedure, which should be considered in such a state of proceedings as valid.

Another issue which is doubtful in terms of the provision of Article 378a of the Code of Criminal Procedure and respecting the guiding principle of the criminal proceedings, i.e. the right of defence of the accused, comprises the proper conduct of the hearing of evidence at the stage of jurisdiction proceedings. It should be, in fact, noticed that the hearing of evidence in criminal proceedings undoubtedly 
requires the assistance of a professional so that it could be stated that the right of defence is a genuine right. The right of defence vested in the accused in the criminal proceedings is of a formal character, which is understood as the right to have a defender, as well as being of a substantive character, i.e. the possibility of a substantial defence against charge ${ }^{12}$. Nevertheless, in order to consider these as real, the aforementioned aspects, i.e. formal and substantive, should co-exist at each stage of the criminal proceedings. Despite the fact that it is obvious that all proceedings differ, even if due to the complexity of the case, the number of charges, as well as the number of the accused, it seems unquestionable that certain issues concerning the hearing of evidence in procedural understanding require at least a minimal knowledge of the criminal procedure. It is true that the accused is instructed by the court with regard to the right to ask witnesses and expert witnesses questions, as well as to address all evidence taken. Nonetheless, due to the complexity of criminal proceedings, as well as e.g. the emotionally engaged accused due to the fact that the case concerns his or her criminal liability, the assistance provided by a professional seems to be indispensable. In the scope of the proceedings, for instance, the provisions of Article 171 par. 4 and par. 6 of the Code of Criminal Procedure, in compliance with which it is inadmissible to ask questions suggesting answers, should also be remembered, since this results in dismissal thereof by the court, i.e. as in the case of questions that are insignificant from the point of view of specific proceedings. This issue seems to be crucial, since how should the accused know which of the asked questions in concreto are significant and which are not? Another important issue consists in which of the questions asked of witnesses can be harmful to his or her procedural situation and which are compliant with the function performed by his or her representatives in the proceedings - the function of defence. These aspects prima facie seem to be insignificant, since the court instructs the accused of the rights vested in him or her. However, in practice, and in particular with regard to the issue related to the role of a defender in criminal proceedings, these aspects are of fundamental significance, even if due to the adopted procedural strategy and line of defence. Another issue (stricte related to criminal proceedings) concerning the hearing of evidence is the proper submission of evidence motions, including formulation of the evidence thesis. A lack of basic knowledge in this scope can, in fact, result in dismissing evidence motions by the court and thus hinder the defence in substantive understanding. Another aspect raising doubts as to the rationality of conducting the hearing of evidence in

12 See: Judgement of the Constitutional Tribunal of 17 February 2004, SK 39/02, LEX no. 84271; Daszkiewicz, W., Proces karny. Część ogólna, Poznań 1995, p. 75; Steinborn, S., in: Steinborn, S. (ed.), Kodeks postępowania karnego. Komentarz do wybranych przepisów, LEX 2016. 
the absence of the defender and concerning the proper course of the proceedings constitutes reacting to the questions asked by the other party - questions suggesting to the witness the answer or questions insignificant from the point of view of the specific criminal proceedings. Due to all of the aforementioned reasons, the defender's participation in the jurisdiction proceedings is necessary. Irrespective of whether the specific case is simple or complex, whether the accused has been presented with one or more charges - due to the procedural issues concerning the principles of conducting the hearing of evidence at the stage of jurisdiction proceedings, whether the accused uses assistance provided by a defender who is not able to participate in the hearing and who has duly justified such absence, the court should interrupt or adjourn the hearing, thus respecting the principle of the right of defence.

\section{Motion for supplementary hearing of evidence}

In the further part of the new provision, the legislator indirectly confirms that conducting the hearing of evidence in the absence of the defender is a wrong solution; wrong in the meaning of the potential possibility of fully conducting the hearing of evidence in the absence of the defender. In compliance with the contents of the provision of Article 378a par. 3 of the Code of Criminal Procedure, there is a possibility of submitting a motion by the accused or the defender aimed at the supplementary hearing of evidence which has been conducted in his or her absence. Therefore, it indicates that the solution consisting in the possibility of conducting the hearing of evidence in compliance with Article 378a par. 1 of the Code of Criminal Procedure actually prevents the conducting of the hearing of evidence reliably. In other words, in criminal proceedings, each of the appearing individuals performs specific functions. The prosecutor - the function of prosecuting, the defender - the function of defending, and the court - the function of adjudicating. Thus, participation of all of the aforementioned entities (and performance by them of their procedural roles) is necessary. For instance, examination of an expert witness in order to issue a supplementary oral opinion can be indicated. In the case of any defects of the opinion (which is unfavourable for the accused), the role of the defender will be to indicate them in the pending proceedings and to possibly submit a motion for giving an opinion by another expert witness. In the absence of the defender during pending proceedings, one cannot be certain whether the court will notice such a necessity and will, ex officio, admit the evidence from the opinion given by another expert witness. 
However, the above right can be executed not later than at the next term of the hearing, of which the accused/his or her defendant has been duly notified and, furthermore, if there are no procedural obstacles preventing their appearance. Nevertheless, the legislator reserves in the last sentence of the provision of Article 378a par. 3 of the Code of Criminal Procedure that the right to submit a motion for supplementary taking of evidence is not vested if the absence of the defender/accused at the last term of the hearing was not duly justified. In the case of a failure to submit such a motion with preservation of the indicated period of time, the right to submit it expires, which results from the contents of Article 378a par. 4 of the Code of Criminal Procedure. In the further part of the provision, the legislator then specifies that, in the course of further proceedings, as a result of taking specific evidence in the absence of the accused or his or her defender, there is no possibility to raise a plea that would indicate that procedural safeguards have been violated (including, in particular, the right of defence expressed in Article 6 of the Code of Criminal Procedure).

In compliance with the wording of the provision of Article 378a par. 5 of the Code of Criminal Procedure, in the case of submitting the motion referred to in par. 3, the accused or his or her defender is obliged to prove that the accused's procedural safeguards have been violated (in particular the right of defence) by "the manner of taking evidence" during the hearing at which the accused or his or her defender was absent. The above solution adopted by the legislator seems to be irrational even if due to the fact that the court, as the authority adjudicating such a motion, would have to state that it has violated the procedural provisions in the scope concerning the accused's right of defence. Such a regulation is paradoxical. On the one hand, the issue concerning the indication that the accused's right of defence has been violated should, in principle, boil down to showing that during the hearing of evidence, witnesses or expert witnesses were not asked any questions significant in terms of the accused's criminal liability. On the other hand, in the case of taking into consideration such a motion, the court would undermine the correctness of taking evidence at the hearing at which the accused or his or her defendant was absent. In the case of taking into consideration the motion submitted by the accused or his or her defendant, the court takes evidence in a manner aimed solely at supplementing the evidence, whereas the legislator indicated that it can take place only in the scope in which it has been proved that the accused's procedural safeguards have been violated (in particular, the right of defence vested in him or her). The above results from the contents of Article 378a par. 6 of the Code of Criminal Procedure. In the scope concerning the motion for supplementary taking of evidence, the opinion that stating by the defender or the accused that they 
did not have the opportunity, due to their absence, to make direct observations with regard to taken evidence should be considered just. ${ }^{13}$

From the point of view of the constitutionally equivocal solution included in Article 378a of the Code of Criminal Procedure, par. 7 thereof should be indicated as the safeguarding element. In compliance with the said provisions, in the case of the absence of a defender or the accused, the court is obliged to instruct that there is a possibility of submitting a motion (by the accused or his or her defender) aimed at supplementary taking of evidence (which has been taken in their absence).

\section{Relationship between Articles 378a and $390 \$ 2$ of the Code of Criminal Procedure}

In the scope concerning the issue of the paper, it is also worth noticing the provision of Article 390 par. 2 of the Code of Criminal Procedure, in compliance with which it is possible to temporarily remove the accused from the courtroom. It should be noticed that, in principle, he or she has the right to participate in all activities related to taking evidence. However, the exception provided for in par. 2 of the aforementioned provision prevents him or her from exercising the right of defence in the state of proceedings in which his or her defender would not participate in the hearing. In fact, in compliance with the wording of the invoked Article, in special circumstances, due to the fear that the presence of the accused would impede explanations given by the co-accused or the testimony given by a witness or an expert witness, the president can then issue an order that for the time of examining such a person, the accused must be absent from the courtroom. However, the issue seems to be outdated in the situation provided for in par. 3 of Article 390 of the Code of Criminal Procedure - allowing for examining the aforementioned category of persons remotely with the use of technical devices, in the case of the state of proceedings, in which the accused leaves the courtroom due to the order issued by the president, and his or her right of actual defence becomes a fictional right. Therefore, it should be assumed that in such a state of proceedings, it should be deemed inadmissible to conduct the hearing in the absence of the defender. The above compilation of provisions of Article 378a of the Code of Criminal Procedure with the provision of Article 390 par. 2 of the Code of Criminal Procedure illustrates this issue well. In such a case, in light of the binding provisions of the Code of Criminal Procedure, the court has the possibility to continue taking evidence.

13 See: Zagrodnik, J. et al., in: Zagrodnik, J. (ed.), Kodeks postępowania karnego. Komentarz praktyczny do nowelizacji 2019, LEX. 
However, such a solution shows the defectiveness of the new Article 378a of the Code of Criminal Procedure from the point of view of the accused's safeguards in criminal proceedings.

\section{Conclusion}

To sum up the above reflections regarding the court's refusal to take into consideration the defender's motion for adjournment of the term of a hearing due to his or her illness confirmed with a sick leave issued by a pathologist, in the first place, it should be noticed that the new regulation is an equivocal solution in terms of the rights vested in the accused. This remains, in fact, in contrast with one of the guiding principles of the criminal procedure, i.e. the constitutionally guaranteed principle of the right of defence. Thus, it is difficult to agree with the fact that due to the entry into force of Article 378a of the Code of Criminal Procedure, Polish criminal proceedings still deserve the quality of a fair trial. Doubtlessly, the judges are currently responsible for whether the constitutional rights of the accused are respected at the stage of the jurisdiction proceedings. It should be noticed that a specific state of proceedings not taking into consideration the defender's motion for adjournment of the term of the hearing (justifying his or her absence with a sick leave issued by a pathologist) will constitute a violation of the accused's right of defence. Nevertheless, the new Article 378a of the Code of Criminal Procedure has positive aspects. It should be indicated that in cases where there are at least several accused, and the case is multithreaded, and specific evidence will be taken at the term of the hearing in which the defender will not be able to participate, application of the aforementioned provision (and, as a result, not taking into consideration the defender's motion for adjournment of the term of the hearing) will certainly not constitute a violation of the accused's right of defence. A situation similar to the aforementioned will take place when the accused is represented by several defenders, then not taking into consideration the motion submitted by one of them (in the absence of another defender at the hearing) also does not constitute a violation of the right of defence of the accused. Nonetheless, the solution adopted by the legislator should be assessed negatively, as it provides the possibility to infringe upon the fundamental principle of Polish criminal proceedings, i.e. the right of defence vested in the defendant. As a result, it will not be possible to state that Polish criminal proceedings (as a result of the improper application of the provision of Article 378a par. 1 of the Code of Criminal Procedure in jurisdiction proceedings) deserve to be defined as a fair trial. 


\section{References}

Daszkiewicz, W., Proces karny. Część ogólna, Poznań 1995.

Grzegorczyk, T. and Tylman, J., Polskie postępowanie karne, Warszawa 2014.

Kosonoga, J., in: Stefański, R. and Zabłocki, S. (eds.), Kodeks postępowania karnego. Tom

I. Komentarz do art. 1-166, LEX.

Misztal, P., in: Świecki, D. (ed.), Meritum. Postępowania karne, Warszawa 2019.

Murzynowski, A., Istota i zasady procesu karnego, Warszawa 1994.

Prusak, F., Kodeks postępowania karnego. Komentarz, LEX.

Siewierski, M. et al., Postępowanie karne w zarysie, Warszawa 1971.

Steinborn, S., in: Steinborn, S. (ed.), Kodeks postępowania karnego. Komentarz do wybranych przepisów, LEX 2016.

Wiliński, P., Pojęcie rzetelnego procesu karnego, in: Wiliński, P. (ed.), Rzetelny proces kar$n y$, LEX.

Zagrodnik, J. et al., in: Zagrodnik, J. (ed.), Kodeks postępowania karnego. Komentarz praktyczny do nowelizacji 2019, LEX.

\section{CITATION}

Ignasiak, M., Refusal to adjourn a hearing due to the defender's being ill vs. execution of the right of defence - comments on Article 378a $\$ 1$ of the Polish Code of Criminal Procedure, "Acta Iuris Stetinensis" 2020, No. 2 (Vol. 30), 21-33, DOI: 10.18276/ais.2020.30-02. 